\title{
Prevalence of a type-I interferon immune response against malaria liver stage infection
}

\author{
Peter Liehl ${ }^{1 *}$, Miguel Prudêncio ${ }^{1}$, Céline Carret $^{2}$, Maria M Mota ${ }^{1}$ \\ From Parasite to Prevention: Advances in the understanding of malaria \\ Edinburgh, UK. 20-22 October 2010
}

Plasmodium sporozoites, transmitted to the mammalian host through a mosquito bite, travel to the liver, where they invade hepatocytes and develop into a form that is then able to infect red blood cells [1]. In spite of the importance of innate immunity in controlling microbial infections, very little is known about its role during the liver stage of malaria infection.

To determine which type of innate immune response is triggered by Plasmodium berghei ANKA sporozoites during the liver stage of malaria we investigated transcriptome variations in this organ 40 hours after infection. We identified 69 genes, mainly classical type-I interferon stimulated genes, whose expression was induced at least 2-fold in comparison to non-infected control mice. Strikingly, the expression of all induced genes was reduced in Plasmodium-infected mice lacking a functional type-I interferon receptor (IFNAR1). Furthermore, we observed a 2-3 fold increase of liver parasite load in IFNAR1-deficient mice compared to their wild-type counterparts. Conversely, infection of wild-type mice after pre-stimulation of the type-I interferon response led to a reduction in liver infection.

Altogether, our data demonstrate for the first time that Plasmodium berghei sporozoites are able to induce a type-I interferon immune response in the liver and that this innate immune response contributes to the host resistance during the malaria liver stage. Future work will address how this immune response is activated during a liver infection by Plasmodium and how it inhibits the infection.

\section{Author details}

'Unidade de Malaria, Instituto de Medicina Molecular, Faculdade de Medicina da Universidade de Lisboa, 1649-028 Lisboa, Portugal. ${ }^{2}$ Unidade de

Unidade de Malaria, Instituto de Medicina Molecular, Faculdade de Medicina da Universidade de Lisboa, 1649-028 Lisboa, Portugal

Full list of author information is available at the end of the article
Parasitologia Molecular, Instituto de Medicina Molecular, Faculdade de Medicina da Universidade de Lisboa, 1649-028 Lisboa, Portugal.

Published: 20 October 2010

Reference

1. Prudêncio M, Rodriguez $A$, Mota MM: The silent path to thousands of merozoites: the Plasmodium liver stage. Nat Rev Microbiol 2006, 4:849-856.

doi:10.1186/1475-2875-9-S2-P19

Cite this article as: Liehl et al:: Prevalence of a type-I interferon immune response against malaria liver stage infection. Malaria Journal 2010 9(Suppl 2):P19.

Submit your next manuscript to BioMed Central and take full advantage of:

- Convenient online submission

- Thorough peer review

- No space constraints or color figure charges

- Immediate publication on acceptance

- Inclusion in PubMed, CAS, Scopus and Google Scholar

- Research which is freely available for redistribution

Submit your manuscript at www.biomedcentral.com/submit
C Biomed Central

() 2010 Liehl et al; licensee BioMed Central Ltd. This is an open access article distributed under the terms of the Creative Commons Attribution License (http://creativecommons.org/licenses/by/2.0), which permits unrestricted use, distribution, and reproduction in any medium, provided the original work is properly cited. 